\title{
PENGARUH KARAKTERISTIK PEMERINTAH DAERAH, KEPALA DAERAH, TINDAK LANJUT TEMUAN AUDIT TERHADAP OPINI
}

\author{
Ristu Pratiwi dan Y Anni Aryani \\ Magister Akuntansi Universitas Sebelas Maret Surakarta \\ Dosen Fakultas Ekonomi dan Bisnis \\ Email: riestoe17@gmail.com
}

\begin{abstract}
This study aims to examine the influence of local government characteristics, executive characteristics, and follow up of audit findings toward audit opinion. This research was conducted at Indonesian local government. The method of sampling is purposive sampling producing 737 local government. Data source are local government financial statement (LKPD) in Indonesia from 2012 to 2013, and excecutive book profile. Then, the method of data analyze is logistic regression (binomial and ordinal).The results show that level of dependence, wealth, expenditure, follow up on audit findings and tenure are likely to influence audit opinion from two logistic regression; 2) goverment size are likely to influence audit opinion. In contrast, excecutive education is not likely influence audit opinion.
\end{abstract}

Keywords: Local Government Characteristics, Executive Characteristics, Follow Up On Audit Findings, Audit Opinion.

\begin{abstract}
Abstrak: Penelitian ini bertujuan untuk mengetahui pengaruh karakteristik pemerintah daerah, kepala daerah, dan tindak lanjut hasil temuan audit terhadap opini audit. Penelitian ini dilakukan pada pemerintah daerah seluruh Indonesia dengan menggunakan sampel sebanyak 737 pemerintah daerah. Pengambilan sampel dengan metode purposive judgement sampling. Sumber data menggunakan LKPD tahun 2012 dan 2013, dan buku profil kepala daerah, sedangkan metode analisis data menggunakan regresi logistik yaitu binomial dan ordinal yang dibantu dengan software SPSS 17.0 For Windows. Hasil penelitian dari kedua uji tersebut menunjukkan bahwa: 1) variabel independen yang kemungkinan berpengaruh pada opini audit dengan mengunakan kedua uji di atas adalah tingkat ketergantungan, kekayaan, belanja, tindak lanjut, dan masa kerja kepala daerah; 2) ukuran pemerintah daerah signifikan pada uji binomial dan tingkat pendidikan signifikan dengan menggunakan uji ordinal.
\end{abstract}

Kata kunci: karakteristik pemerintah daerah, karakteristik kepala daerah, tindak lanjut hasil temuan audit, opini audit

\section{PENDAHULUAN}

Pengelolaan keuangan negara yang tertib wajib dilakukan pemeriksaan oleh pihak yang independen. Hal tersebut dilaksanakan agar pengelolaan negara berjalan dengan efektif, ekonomis, transparan, dan bertanggungjawab. Pengelolaan keuangan yang dituangkan dalam laporan keuangan diperiksa oleh pihak eksternal dan indpenden. Laporan keuangan negara diperiksa oleh Badan Pemeriksa Keuangan (BPK) yang mandiri dan bebas. BPK akan menyusun laporan hasil pemeriksaan atas laporan keuangan setelah melakukan pemeriksaan. Laporan tersebut memuat opini. BPK mengeluarkan empat 
macam opini, yaitu Opini Wajar Tanpa Pengecualian (WTP), Opini Wajar Dengan Pengecualian (WDP), Opini Tidak Wajar (TW), dan Opini Tidak Memberikan Pendapat (TMP).

Perkembangan opini audit BPK terhadap laporan keuangan pemerintah semakin membaik dari tahun ke tahun. Laporan keuangan pemerintah tahun anggaran 2013 yang memperoleh opini WTP kurang lebih sebesar 50 \%. Laporan Keuangan Pemerintah Pusat (LKPP) tahun 2013 belum meraih opini WTP. Laporan Keuangan Kementrian Lembaga (LKLL) yang meraih opini WTP sebesar 74 \%. Laporan Keuangan Pemerintah Daerah (LKPD) yang meraih opini WTP sebesar $34 \%$, dan Laporan Keuangan Badan Lain sebesar 60 \% yang meraih opini WTP (BPK, 2014). Rencana Pembangunan Jangka Menengah Nasional (RPJMN) tahun 2010-2014 target opini WTP adalah $100 \%$ untuk LKLL dan $60 \%$ untuk LKPD. Berdasarkan data tersebut dapat diketahui bahwa persentase opini WTP pada LKPD mempunyai persentase terendah dibandingkan dengan laporan keuangan pemerintah yang lain dan realisasi target dalam RPJMN juga masih kecil.

Faktor-faktor yang mempengaruhi pemberian opini audit BPK harus diperhatikan oleh masing-masing daerah khususnya kepala daerah. Kepala daerah merupakan pemegang kekuasaan eksekutif yang dipercaya oleh para stakeholder untuk menjalankan pemerintahan di suatu daerah. Peran dan komitmen dari kepala daerah sangat penting dalam rangka upaya daerah dalam meraih opini audit WTP dari BPK.

Opini dari auditor mempunyai pengaruh terhadap stakeholder, para manager akan berusaha untuk mendapatkan opini wajar tanpa pengecualian dari laporan keuangan perusahaannya. Laporan keuangan yang di audit akan mengurangi asymetry informasi yang terjadi antara principal dan agent. Opini dari auditor memegang peranan penting dalam menentukan integritas informasi dari laporan keuangan yang di audit (Chang, Dasgupta, dan Hilary, 2009).

Stakeholder dari pemerintah daerah membutuhkan informasi yang berkualitas dari LKPD yang dipertanggungjawabkan oleh kepala daerah. Oleh karena itu, audit pada LKPD sangat diharapkan mampu mencerminkan kualitas dari laporan keuangan tersebut. BPK selalu mendorong pemerintah daerah untuk meningkatkan pengelolaan dan pertanggungjawaban keuangan negara dengan memantau tindak lanjut hasil temuan audit. Kualitas pengelolaan dan pertanggungjawaban keuangan akan meningkat jika tindak lanjut hasil temuan audit berjalan efektif. Peningkatan opini WDP menjadi WTP menurut BPK disebabkan pemerintah daerah melakukan perbaikan-perbaikan kelemahan pada LKPD tahun sebelumnya. Dalam IHPS Semester I tahun 2014 menyatakan bahwa peningkatan opini audit BPK pada LKPD antara lain disebabkan oleh: (1) perbaikan sistem pengelolaan belanja; (2) peningkatan inventarisasi aset tetap; (3) perbaikan sistem piutang, persediaan, investasi, dan hutang. Selain itu, BPK juga menyatakan bahwa pemerintah daaerah masih mempunyai permasalahan, yaitu pengalihan kewenangan pungutan PBB dari pusat ke daerah. Permasalahan yang timbul tersebut jika tidak segera diselesaikan akan menyebabkan hilangnya potensi pendapatan daerah. Pengalihan kewenangan tersebut bertujuan untuk meningkatkan pendapatan asli daerah (PAD).

Oleh karena itu, pengaruh karakteristik pemerintah daerah yang tersaji dalam LKPD, karakteristik kepala daerah, dan tindak lanjut audit periode sebelumnya terhadap opini audit BPK merupakan hal yang menarik untuk diteliti lebih lanjut. Menurut Nora (2003) karakteristik perusahaan, karakteristik top management, dan lingkungan perusahaan berpengaruh positif dan signifikan pada pada kinerja pada perusahaan kecil. Penelitian 
terdahulu menunjukkan bahwa faktor-faktor yang mempengaruhi opini audit BPK antara lain yaitu realisasi belanja publik (Nurdiono, 2014) tipe atau jenis pemerintah daerah (Husnatarina dan Halim, 2013), ukuran pemerintah daerah, populasi, tipe pemerintah daerah, asistensi oleh BPKP (Nuraeni dan Martani, 2012), temuan terhadap ketidakpatuhan peraturan perundang-undangan, dan opini audit tahun lalu (Safitri, 2014; Fatimah, Sari, dan Rasuli, 2014; Rusherlistyani, 2014), politik dinasti, jangka waktu pemilihan kepala daerah, index pembangunan manusia (Adzani dan Martani, 2014), kelemahan sistem pengendalian intern (Kawedar, 2010), dan pengungkapan LKPD (Haryadi, Kamaliah, dan Ratnawati, 2015)

Penelitian ini mengacu pada penelitian Nuraeni dan Martani (2012) dan Nurdiono (2014) dengan disesuaikan dengan permasalahan pada LKPD di Indonesia yang dirangkum dalam IHPS I tahun 2014 yang dikeluarkan oleh BPK. Pemerintah daerah masih memiliki permasalahan mengenai pengelolaan aset daerah, belanja, dan pendapatan asli daerah dalam mencapai target opini WTP. BPK juga masih menemukan bahwa pemerintah daerah kurang optimal dalam menindaklanjuti hasil temuan audit. BPK merekomendasikan kepada kepala daerah untuk terus melakukan monitoring dan evaluasi terhadap pengelolaan keuangan di daerah.

Karakteristik pemerintah daerah diwakili oleh kekayaan, ukuran, dan tingkat ketergantungan pemerintah daerah terhadap pemerintah pusat berdasarkan penelitian Nuraeni dan Martani (2012). Ukuran pemerintah daerah berpengaruh terhadap opini audit namun mempunyai korelasi negatif sedangkan menurut De Angelo (1981), Deis dan Giroux (1992); Setyaningrum (2012); dan Habib (2013) ukuran organisasi berhubungan negatif dengan kualitas audit yang berarti mempunyai korelasi positif dengan opini audit. Tingkat ketergantungan pemerintah daerah terhadap pemerintah pusat tidak berpengaruh terhadap opini (Nuraeni dan Martani, 2012) sedangkan menurut Ingram (1984 dalam Martani dan Lestiani 2012) bahwa tingkat ketergantungan pemerintah daerah yang tinggi kepada pemerintah pusat akan membuat daerah mematuhi peraturan yang berlaku. Kepatuhan pemerintah daerah terhadap peraturan perundang-undangan yang berlaku akan meningkatkan opini audit. Kekayaan pemerintah daerah yang diukur dari PAD tidak berpengaruh terhadap opini audit (Nuraeni dan Martani, 2012) sedangkan menurut Laswad dkk. (2005); Mustikarini dan Fitriasari (2012) kekayaan daerah berpengaruh pada tingkat pengungkapan pada laporan keuangan. Pendapatan yang besar menuntut pertanggungjawaban yang tinggi dari pemerintah daerah. Oleh karena itu, pemerintah daerah akan berhati-hati dalam mengelola PAD.

Variabel tindak lanjut hasil temuan audit dan realisasi belanja berdasarkan penelitian Nurdiono (2014). Nurdiono (2014) menemukan bahwa belanja publik berpengaruh secara negatif terhadap opini audit namun pada penelitian Safitri (2014) besarnya realisasi anggaran pendapatan dan belanja tidak berpengaruh terhadap opini audit. Belanja yang besar mencerminkan jumlah dan kompleksitas kegiatan pemerintah daerah jika tidak dikelola secara hati-hati akan menyebabkan banyaknya penyimpangan-penyimpangan sehingga menurunkan opini audit. Menurut Nurdiono (2014) tindak lanjut hasil temuan audit tidak berpengaruh terhadap opini audit seharusnya tindak lanjut hasil temuan audit bertujuan untuk meningkatkan keefektifan pengelolaan keuangan daerah. Adzani dan Martani (2014) menyatakan bahwa jumlah temuan dan rekomendasi serta nominal temuan berpengaruh terhadap opini audit. BPK terus melakukan pemantauan tindak lanjut hasil temuan audit tahun sebelumnya pada saat melakukan pemeriksaan tahun berjalan. 
Penelitian ini menambahkan karakteristik kepala daerah karena salah satu kewajiban kepala daerah adalah melaksanakan pengelolaan keuangan daerah dan mempertanggungjawabkannya. Menurut Adzani dan Martani, (2014) proses politik dan pengelolaan keuangan daerah ditentukan oleh kepala daerah selaku eksekutif, DPR selaku legislatif, dan auditor sebagai kontroler. Menurut Adzani dan Martani (2014) calon kepala daerah incumbent cenderung menyajikan laporan keuangan yang berkualitas sehingga meningkatkan opini audit. Karakteristik kepala daerah berdasarkan penelitian Seeba dkk. (2009). Penelitian ini menyatakan bahwa umur tidak berpengaruh terhadap kinerja perusahaan, sedangkan menurut upper echelon theory umur berhubungan dengan tujuan strategis perusahaan. Dua karakteristik lain dalam penelitian Seeba dkk. (2009) adalah tingkat pendidikan dan masa kerja keduanya mempengaruhi kinerja perusahaan. Hal ini sesuai dengan upper echelon theory, namun penelitian Fernandez dkk. (2015) dan Sitthipongpanich dan Polisri (2015) menyatakan bahwa tingkat pendidikan tidak berpengaruh terhadap kinerja perusahaan. Damanpour dan Schneider, (2008) menyatakan bahwa manajer yang mempunyai masa kerja yang lama cenderung telah terbiasa dengan rutinitas sehingga tidak tertarik untuk mengubah kondisi yang sudah ada atau tidak melakukan inovasi.

Penelitian ini bermanfaat bagi kepala daerah agar bisa meningkatkan kinerja di bidang keuangan dengan mengetahui faktor-faktor yang mempengaruhi opini audit. Bagi regulator hendaknya mempertimbangkan karakteristik kepala daerah dalam membuat peraturan perundang-undangan mengenai kepala daerah.

\section{KAJIAN TEORI}

Agency Theory. Pemerintah adalah sebuah organisasi yang besar dan komplek, sebagai sebuah organisasi yang besar maka pemerintah harus dikelola dengan baik. Pengelolaan organisasi pemerintah sebagaimana organisasi sektor swasta dikelola oleh sekelompok orang yang diberi kepercayaan untuk mengelola organisasi. Pada sektor swasta para stakeholder yang disebut principal dan orang yang diberi kuasa disebut agent. Teori tersebut dikenal dengan agency theory

Penelitian Jensen dan Meckling (1976) dan Ross (1973) menyatakan bahwa hubungan keagenan merupakan kontrak yang melibatkan satu atau lebih principal dengan agent untuk melaksanakan pekerjaan yang melibatkan sebagian pelimpahan wewenang dalam pengambilan keputusan dari principal kepada agent. Pelimpahan sebagian wewenang dari principal kepada agent akan mengakibatkan agent tidak selalu bertindak sesuai dengan keinginan dari principal karena agent mempunyai kepentingan sendiri.

Menurut Eisenhart (1989) agency theory bertujuan untuk mempelajari pemecahan permasalahan dalam hubungan keagenan. Permasalahan tersebut terdiri dari dua masalah pokok, yaitu (1) ada konflik tujuan dari principal dan agents dan (2) terlalu sulit atau mahal bagi principal untuk mengetahui yang dilakukan oleh agent. Permasalahan kedua adalah permasalahan risk sharing yang timbul ketika principal dan agent terdapat perbedaan tindakan dalam menyikapi resiko.

Sistem desentralisasi yang dimulai tahun 1999 yang ditandai dengan adanya penyerahan wewenang pemerintahan kepada daerah otonom dalam kerangka NKRI. Menurut Halim dan Abdullah (2006) dalam otonomi daerah terdapat hubungan keagenan antara legislatif dan eksekutif dalam bidang akuntansi mulai dari perencanaan, 
penganggaran, dan pertanggungjawaban. Eksekutif berlaku sebagai dual agent dari dua principal legislatif dan rakyat.

Eksekutif yaitu kepala daerah mempunyai informasi keuangan daerah yang lebih banyak daripada legislatif dan rakyat. Legislatif menilai pertangungjawaban keuangan daerah setiap tahun anggaran. Laporan keuangan tersebut harus terlebih dahulu diperiksa oleh pihak yang independen yaitu BPK untuk mengetahui kualitas dari laporan keuangan yang disampaikan.

Upper Echelon Theory. Upper echelon theory merupakan teori yang berpandangan bahwa outcomes dari organisasi, yaitu pilihan strategis dan tingkat kinerja sebagian dapat diprediksi melalui karakteristik latar belakang manajerial (Hambrick dan Manson 1984). Proses dari strategi perusahaan atau organisasi tidak bisa lepas dari keterlibatan individuindividu dalam organisasi. Nilai dan kognitif dari individu yang berpengaruh dalam organisasi yaitu top manager berperan besar menentukan outcomes organisasi, sehingga hal ini dapat diteliti secara empiris.

Pada upper echelon theory hanya menggunakan data demografi dari top management atau TMT. Untuk mengetahui hubungan antara individu, organisasi, dan lingkungannya membutuhkan penelitian dengan pendekatan berbagai disiplin ilmu seperti psikologi, sosial, dan ekonomi. Upper echelon theory mengesampingkan beberapa pendekatan seperti proses psikologi top management. Hal ini merupakan kelemahan dari teori ini.

Kelebihan dari teori ini antara lain adalah lebih mudah untuk memprediksikan karakteristik top management yang mempengaruhi outcomes organisasi. Para pembuat kebijakan juga dapat menggunakan dasar teori ini dalam memilih top management yang akan mengelola organisasi dengan melihat karakteristik demografi calon top management seperti umur, tingkat pendidikan, latar belakang pendidikan, pengalaman, dan karakteristik yang lain. Manfaat lain yang dapat diambil adalah untuk melihat karakteristik demografi top management organisasi pesaing yang lebih maju apakah dipimpin oleh top management yang berumur atau muda dan lain sebagainya. Upper echelon theory ini mulai dikembangkan setelah Hambrick dan Manson (1984) mengembangkan preposisi yang dapat digunakan untuk penelitian-penelitian lebih lanjut mengenai upper echelon theory.

Penelitian mengenai upper echelon theory berkembang sampai dengan saat ini. Demografi dari top management atau team top management berpengaruh pada outcome perusahaan dilakukan oleh Hutzschenreuter dan Horstkotte, 2012; Fernandez dkk., 2015; Amran, Yusof, Ishak, dan Arinin, 2014; Bamber, Jiang, dan Wang 2010; Finkelstein dan Hambrick 1990; Seeba, Wallace, dan Cornelius 2009; Michel dan Hambrick, 1992.

Opini Audit. BPK merupakan lembaga pemeriksa keuangan negara yang diamanahkan dalam UUD 1945.Tujuan dilaksanakannya pemeriksaan atas laporan keuangan salah satunya untuk memberikan opini atas kewajaran informasi keuangan yang disajikan dalam laporan keuangan. Opini yang dimuat ada empat macam opini yaitu Opini Wajar Tanpa Pengecualian (WTP), Opini Wajar Dengan Pengecualian (WDP), Opini Tidak Wajar (TW), dan Opini Tidak memberikan pendapat (TMP). Ada beberapa kriteria yang mempengaruhi BPK dalam memberikan opini pada laporan keuangan. Kriteria tersebut antara lain adalah evaluasi atas keefektifan Sistem Pengendalian Internal (SPI) dan didasarkan pada penilaian kepatuhan terhadap ketentuan peraturan perundang-undangan. 
Karakteristik Pemerintah Daerah. Menurut Kamus Bahasa Indonesia (KBI) tahun 2008 karakteristik adalah mempunyai sifat khas dengan perwatakan tertentu. Menurut Suhardjanto dan Yulianintyas (2011) ciri-ciri khusus yang melekat pada pemerintah daerah yang membedakannya dengan daerah lain.

Karakteristik pemerintah daerah berhubungan dengan kualitas informasi yang dihasilkan oleh pemerintah daerah (Martani dan Liestiani, 2012). Karakteristik daerah sebagai variabel prediktor yang mempengaruhi pengungkapan pada laporan keuangan pemerintah (Zimmerman, 1977; Robbins dan Austin, 1986; Laswad dkk., 2005; Giroux dan McLelland, 2003). Patrick (2007) menyatakan ukuran pemerintah daerah berpengaruh pada inovasi organisasi.

Karakteristik pemerintah daerah dapat sebagai prediktor pengungkapan LKPD (Suhardjanto dan Lesmana, 2010; Suhardjanto dan Yulianingtyas, 2011; Setyaningrum dan Syafitri, 2012; Hilmi dan Martani, 2012; Heriningsih dan Rusherlistyani, 2013; Susbiyani, Suroto, Sutrisno, dan Purnomosidi, 2014; Martani dan Liestiani, 2012), kinerja pemerintah daerah (Sumarjo, 2010; Mustikarini dan Fitriasari, 2012; Sudarsana, 2013; Marfiana dan Kurniasih, 2013), kualitas audit (DeAngelo, 1981; Deis dan Giroux, 1992; Setyaningrum 2012), pemberian opini oleh auditor (Caramanis dan Sphatis, 2006;Nuraeni dan Martani, 2012; Adzani dan Martani, 2014; Nurdiono 2014; Husnatarina dan Halim 2013).

Karakteristik Kepala Daerah. Kepala daerah menurut UU No. 22 Tahun 1999 merupakan badan eksekutif daerah yang pelaksanaan tugasnya dibantu oleh perangkat daerah otonomi yang lain sebagai badan. Pemerintah daerah bersama dengan DPRD menyelenggarakan pemerintahan daerah otonom menurut asas desentralisasi. Sistem desentralisasi memberikan kewenangan bagi kepala daerah untuk mengatur dan mengurus kepentingan masyarakat setempat menurut prakarsa sendiri berdasarkan aspirasi masyarakat. Pemerintah pusat melimpahkan kewenangan dan tanggung jawab pengelolaan daerah kepada kepala daerah. Pertanggungjawaban dan akuntabilitas keuangan daerah diatur oleh kepala daerah (Nordiawan dan Hertianti, 2010: 25).

Peran kepala daerah dalam meningkatkan akuntabilitas dan transparansi pemerintah daerah sangat penting. Kepala daerah terpilih diharapkan adalah kepala daerah yang mempunyai kompetensi. Kompetensi manager pada sektor publik mempengaruhi ketepatan waktu penyampaian laporan keuangan (Dwyer dan Wilson, 1989), dan pemilihan eksternal auditor (Zimmerman, 1977). Outcomes dari sebuah organisasi baik sasaran strategis dan keefektifan merupakan refleksi nilai dan kognitif dari “aktor” di belakang itu semua. Data demografi manager potensial sebagai prediktor dari sasaran strategis dan tingkat kinerja organisasi (Hambrick dan Manson, 1984).

Tindak Lanjut Temuan Audit. Saran yang berdasarkan hasil pemeriksaan adalah rekomendasi. Menurut UU No 15 Tahun 2004 pejabat yang diperiksa mempunyai kewajiban untuk menindaklanjuti rekomendasi BPK lengkap dengan jawaban dan penjelasan. Tindak lanjut tersebut dilaksanakan maksimal 60 hari setelah hasil laporan pemeriksaan diterima.

Menurut Johnson, Lowensohn, Reck, dan Davies (2012) management letter comment berhubungan dengan kualitas laporan keuangan. Tindak lanjut hasil temuan audit yang dilaksanakan diharapkan mampu memperbaiki kelemahan-kelemahan yang ada sebelumnya, sehingga hal tersebut akan berdampak pada peningkatan kualitas laporan 
keuangan pemerintah daerah yang disajikan oleh pemerintah daerah Good governance suatu pemerintah daerah dipengaruhi oleh tindak lanjut hasil temuan audit (Arifianti dkk., 2014; Sari, 2013).

Pengembangan Hipotesis. Karakteristik Pemerintah daerah. Ukuran Pemerintah Daerah. Ukuran suatu organisasi dapat diukur dengan total aset, jumlah karyawan, dan total pendapatan. Pada sektor publik ukuran pemerintah daerah dapat diukur dari total aset, jumlah penduduk, jumlah SKPD, dan jumlah legislatif. Pengelolaan organisasi membutuhkan sumber daya yang cukup dalam mencapai tujuan organisasi. Ukuran sebuah organisasi yang di audit dan kesehatan keuangan klien mempunyai pengaruh negatif pada kualitas audit (DeAngelo, 1981; Deis dan Giroux, 1992; Habib, 2013; Setyaningrum, 2012). Pada perusahaan besar cenderung menyajikan laporan keuangan yang jauh dari salah saji.

Menurut Damanpour dan Schneider (2008), organisasi yang besar mempunyai sumber daya ekonomi yang lebih baik dalam mengadopsi inovasi.. Penelitian Zaelani (2010, dalam Nuraeni dan Martani, 2012) menyatakan bahwa ukuran organisasi yang besar mempunyai sistem pengendalian yang kuat. Jika sistem pengendalian kuat maka laporan keuangan yang dihasilkan akan lebih berkualitas. Penelitian Nuraeni dan Martani (2012) tidak berhasil membuktikan hal tersebut, penelitian ini menyatakan bahwa ukuran pemerintah daerah berhubungan negatif dengan opini audit BPK semakin besar ukuran pemerintah daerah maka semakin besar kemungkinan untuk memperoleh opini yang buruk dari BPK. Hal ini disebabkan karena pemerintah daerah kurang bisa mengelola jumlah aset yang besar. Berdasarkan penelitian di atas maka hipotesis pertama dalam penelitian ini mengacu pada penelitian (DeAngelo, 1981; Deis dan Giroux, 1992; Setyaningrum, 2012; Habib 2013; Zaelani 2010 dalam Nuraeni dan Martani, 2012) maka hipotesis pertama adalah sebagai berikut ini.

H1: Ukuran Pemerintah Daerah yang besar kemungkinan mendapatkan opini yang lebih baik dari BPK

Tingkat Ketergantungan Pemerintah Daerah pada Pemerintah Pusat. Pemerintah Daerah masih mempunyai ketergantungan pada pemerintah pusat salah satunya berupa Dana Alokasi Umum (DAU). Tujuan diberikan DAU adalah untuk sistem pemerataan. Daerah dengan kemampuan fiskal kecil dan kebutuhannya besar akan mendapat DAU besar (Nordiawan dan Hertianti, 2010: 26). Tingkat ketergantungan daerah kepada pemerintah pusat akan cenderung membuat pemerintah daerah lebih menaati peraturan yang berlaku. Tingkat ketergantungan pemerintah daerah berpengaruh pada positif pada kinerja pemerintah daerah (Susbiyani dkk., 2014; Mustikarini dan Fitriasari, 2012). Tingkat ketergantungan pemerintah daerah berpengaruh positif pada pengungkapan laporan keuangan (Ingram 1984 dalam Martani dan Lestiani 2012; Robin dan Austin 1986). Pada penelitian Nuraeini dan Martani (2012) menyatakan bahwa tingkat ketergantungan pemerintah daerah tidak berpengaruh pada opini yang diberikan oleh BPK. Tingkat ketergantungan pemerintah daerah kepada pemerintah pusat yang semakin besar sewajarnya membuat pemerintah daerah lebih berhati-hati dalam melaksanakan penatausahaan keuangan, sehingga LKPD tersaji sesuai dengan peraturan dan perundangundangan yang berlaku. Berdasarkan penelitian diatas maka dikembangkan hipotesis kedua sebagai berikut ini.

H2: Tingkat ketergantungan pemerintah daerah terhadap pemerintah pusat yang tinggi kemungkinan mendapatkan opini yang lebih baik dari BPK. 
Tingkat Kekayaan Pemerintah Daerah. Kekayaan pemerintah daerah dapat diukur dari pendapatan perkapita penduduk suatu daerah dan pendapatan asli daerah. Pemerintah daerah dengan kekayaan yang besar mampu melakukan pelayanan publik yang optimal. Jumlah kekayaan yang besar mencerminkan pemerintah daerah mampu menggali potensipotensi kekayaan daerah. Pengelolaan potensi-potensi daerah yang baik akan mendukung kinerja pemerintah daerah. Kekayaan pemerintah daerah mempunyai pengaruh positif pada pengungkapan LKPD (Laswad dkk., 2005; Setyaningrum dan Syafitri, 2012), dan kinerja pemerintah daerah (Mustikarini dan Fitriasari, 2012). Namun, menurut Johnson dkk. (2012), semakin besar pendapatan mencerminkan lingkup kegiatan yang luas sehingga membutuhkan koordinasi dan kontrol yang tinggi. Menurut Zaelani (2010 dalam Nuraeni dan Martani, 2012) menyatakan bahwa pendapatan yang besar mencerminkan kegiatan yang semakin komplek, sehingga sistem pengendalian intern akan semakin lemah. Sistem pengendalian intern merupakan salah satu dasar pemberian opini audit BPK.

Jika SPI lemah maka opini audit akan semakin rendah. Penelitian Nuraeni dan Martani (2012) dan Safitri (2014) tidak berhasil membuktikan bahwa tingkat kemakmuran atau realisasi pendapatan berpengaruh pada opini yang diberikan oleh BPK. Pemerintah daerah yang mempunyai PAD yang tinggi akan menghadapi tuntutan dari stakeholder khususnya penyumbang PAD dalam hal pertanggungjawabannya. Stakeholder akan lebih mengawasi penggunaan PAD sehingga pemerintah daerah akan lebih berhatihati dalam mengelola PAD. Besarnya PAD juga mencerminkan bahwa pemerintah daerah berhasil mengelola potensi-potensi pendapatan daerah dengan baik sehingga tidak ada potensi pendapatan yang hilang. Berdasarkan uraian tersebut maka dihasilkan hipotesis sebagai berikut ini.

H3: Tingkat kekayaan pemerintah daerah yang tinggi kemungkinan mendapatkan opini yang lebih baik dari BPK.

Realisasi Belanja Pemerintah Daerah. Pelayanan publik yang dilaksanakan oleh pemerintah daerah dituangkan dalam kegiatan-kegiatan pemerintah daerah. Kegiatankegiatan pemerintah daerah menggunakan anggaran belanja agar outcome kegiatan dapat tercapai. Jumlah belanja yang besar pada pemerintah daerah mengindikasikan kegiatan yang dilakukan juga besar dan kompleks. Sistem pengendalian terhadap belanja harus dilakukan sesuai dengan peraturan perundang-undangan yang berlaku agar outcome dapat tercapai. Namun, jika pemerintah daerah tidak berhati-hati dalam penatausahaan pengelolaan belanja maka akan terjadi banyak penyimpangan. Pada saat ini belanja pemerintah daerah masih ditemukan banyak penyimpangan.

Menurut Behn dkk.(2010), belanja berpengaruh positif pada tingkat pengungkapan laporan keuangan organisasi nirlaba. Belanja pemerintah terbukti berpengaruh positif pada kinerja keuangan pemerintah daerah (Marfiana dan Kurniasih, 2013), namun hal ini bertentangan dengan penelitian Mustikarini dan Fitriasari (2012). Menurut Nurdiono (2014) besarnya anggaran belanja publik berdampak negatif pada opini BPK.

Namun, penelitian Safitri (2012) menemukan bahwa realisasi anggaran tidak berpengaruh pada opini audit BPK. Pemerintah daerah dengan realisasi anggaran belanja yang besar pada umumnya mempunyai kompleksitas kegiatan yang besar pula. Anggaran belanja yang besar pada umumnya terdiri dari kegiatan yang banyak oleh karena itu dibutuhkan pengendalian yang memadai. Belanja pemerintah daerah yang besar jika tidak dikelola dengan hati-hati akan menyebabkan terjadinya penyimpangan-penyimpangan. Penyimpangan-penyimpangan yang terjadi akan mempengaruhi auditor dalam 
memberikan opini. Berdasarkan hal tersebut maka hipotesis ke empat adalah sebagai berikut ini.

H4: Tingkat belanja pemerintah daerah yang tinggi kemungkinan mendapatkan opini yang lebih buruk dari BPK.

Tindak Lanjut Hasil Rekomendasi. Berdasarkan press realease BPK, baru 65 \% temuan dan rekomendasi BPK yang ditindaklanjuti. BPK memantau tindaklanjut terhadap temuan dan rekomendasi yang diberikan kepada pemerintah daerah. Tindaklanjut temuan dan rekomendasi dilaksanakan untuk meningkatkan good governance pemerintah daerah. Menurut Sari (2013), prinsip-prinsip tata kelola pemerintah yang baik dipengaruhi adanyan tindak lanjut rekomendasi audit BPK, SPI, dan Implementasi Standar Akuntansi Pemerintah. Penelitian lain menunjukkan bahwa tindak lanjut audit berpengaruh pada kinerja pemerintah daerah Arifianti dkk. (2013). Dalam penelitian Astriani (2014) menyatakan bahwa tindak lanjut temuan audit BPK mempunyai pengaruh yang signifikan terhadap kualitas audit pada LKPD Kabupaten/Kota Propinsi Jawa Barat. Namun, dalam Nurdiono (2014), tindak lanjut temuan audit tidak berpengaruh pada opini audit. Menurut BPK bahwa tindak lanjut hasil temuan audit akan meningkatkan tata kelola keuangan yang baik, tata kelola keuangan yang baik tentu saja akan meningkatkan opini BPK menjadi lebih baik. Berdasarkan uraian diatas maka hipotesis kelima adalah sebagai berikut ini.

H5: Tindak lanjut temuan audit yang tinggi kemungkinan mendapatkan opini yang lebih baik dari BPK.

Karakteristik Kepala Daerah. Tingkat Pendidikan Kepala Daerah. Individu dengan latar pendidikan formal mempunyai informasi yang lebih banyak dan kompleks, karena tingkat pendidikan individu mencerminkan pengetahuan dan skill dasar dari individu tersebut. Oleh karena itu, tingkat pendidikan sangat berpengaruh bagi seseorang. Bagi pemimpin atau top manager, tingkat pendidikan akan membantu dalam pengambilan keputusan sehingga dapat mempengaruhi kinerja perusahaan (Hambrick dan Manson 1984; Amran dkk. 2014; Damanpour dan Schneider, 2008; Prasetya, 2014). Namun, penelitian Fernandez dkk. (2015) dan Sitthipongpanich dan Polisri (2015) menyatakan bahwa tingkat pendidikan dari tim top management tidak berpengaruh pada kinerja perusahaan, karena level pendidikan yang lebih tinggi cenderung memilih strategi yang sesuai dengan minat individu dari top manager. Kepala daerah yang mempunyai tingkat pendidikan yang tinggi diharapkan akan mempunyai informasi yang lebih banyak dalam pengambilan keputusan. Berdasarkan uraian diatas maka terbentuk hipotesis sebagai berikut ini.

H6: Tingkat pendidikan kepala daerah yang tinggi kemungkinan mendapatkan opini yang lebih baik dari BPK.

Umur Kepala Daerah. Umur pada umumnya merupakan ukuran kedewasaan seseorang sehingga akan lebih berhati-hati dalam setiap pengambilan keputusan dan membutuhkan waktu yang lama dalam mengevaluasi informasi. Top manager yang berumur lebih muda akan menyukai tantangan, lebih inovatif dalam meningkatkan strategi perusahaan agar kinerja perusahaan meningkat (Hambrick dan Manson 1984; Amran dkk. 2014; Fernandez dkk., 2015). Manager yang lebih muda dan mempunyai masa jabatan lebih sedikit dapat berpengaruh negatif pada inovasi karena tidak cukup mengenal pekerjaannya dan organisasinya (Damanpour dan Schneider, 2008). Prasetya (2014) membuktikan bahwa umur kepala daerah di Indonesia berpengaruh positif pada kinerja penyelenggaraan 
pemda. Penelitian Seeba dkk. (2009) menyatakan umur tidak berpengaruh, namun berhubungan negatif dengan kinerja perusahaan. Seorang top manager yang berusia lebih muda akan lebih mempunyai inovasi yang tinggi dalam meningkatkan kinerja organisasi. Berdasarkan uraian diatas maka terbentuk hipotesis.

H7: Umur kepala daerah yang besar kemungkinan mendapatkan opini yang lebih buruk dari BPK.

Masa Kerja atau Pengalaman Kepala Daerah. Pengalaman dalam bidang tertentu akan membentuk orientasi top manager dalam bekerja. Pengalaman kerja dapat menentukan orientasi top management dalam menentukan strategi organisasi. Pengalaman kepala daerah adalah masa kerja kepala daerah dalam memimpin suatu daerah. Pengalaman dalam berkarir diharapkan akan mempengaruhi top manager dalam pengambilan keputusan (Hambrick dan Manson, 1984; Seeba dkk., 2009; Qin, 2012; Hutzschenreuter dan Horstkotte, 2012; Damanpour dan Schneider, 2008). Melalui pengalaman top management mendapatkan pengetahuan sehingga akan terbentuk keterampilan dan kompetensi yang unik dalam membangun jaringan. Hambrick dan Manson (1984) menyatakan bahwa dasar pengetahuan kognitif, nilai-nilai, dan persepsi dibentuk dari pengalaman top management. Menurut Fernandez dkk. (2015), pengalaman fungsional tim dari top manager tidak berpengaruh dan berhubungan negatif terhadap kinerja perusahaan. Manager yang berumur dan berpengalaman terbiasa dengan rutinitas tidak tertarik untuk mengubah keadaan tersebut (Huber dkk, 1993 dalam Damanpour dan Schneider, 2008). Namun, pada sektor publik, umur dan masa kerja berhubungan positif dengan inovasi dan perubahan karena senioritas lebih dihormati dan semakin berpengalaman dalam melaksanakan administrasi publik sehingga berminat pada peningkatan kinerja (Kearney, Feldman, dan Scavo, 2000 dalam Damanpour dan Schneider, 2008). Berdasarkan uraian diatas maka hipotesis ke delapan adalah sebagai berikut ini.

H8: Masa kerja kepala daerah yang panjang kemungkinan mendapatkan opini yang lebih baik dari BPK.

\section{METODE}

Populasi, Sampel, dan Teknik Pengambilan Data. Populasi dalam penelitian ini adalah pemerintah daerah Republik Indonesia tahun 2012 dan 2013. Teknik pengambilan sampel menggunakan purposive judgement sampling yaitu bahwa sampel yang diambil berdasarkan kriteria. Kriteria sampel dalam penelitian ini adalah sebagai berikut: (1) Pemerintah Daerah yang diaudit oleh BPK tahun 2012 dan 2013 serta tercantum dalam IHPS I Tahun 2014 yang dikeluarkan oleh BPK di website BPK www.bpk.go.id; (2) Pemerintah Daerah yang LKPD-nya ada dalam sumber data yang dimiliki peneliti; (3) Pemerintah Daerah yang profil kepala daerahnya ada dalam buku profil kepala daerah pilkada tahun 2010, 2011, 2012, dan 2013 yang diterbitkan oleh Direktorat Jenderal Otonomi Daerah Kementrian Dalam Negeri RI.

Definisi Operasional dan Pengukuran Variabel. Penelitian ini menggunakan variabel dependen dan independen, definisi dan pengukuran variabel adalah sebagai berikut ini. Pertama. Varibel dependen. Variabel dependen dalam penelitian ini adalah opini audit BPK. Menurut Buletin Teknis SPKN Nomor 01, opini audit terdiri dari WTP dan atau 
WTP DPP, WDP, TW, dan TMP. Ukuran variabel dependen pada model pertama adalah WTP dan WTP-DPP $=1$ dan opini WDP, TW, TMP $=0$. Ukuran variabel pada model kedua adalah opini WTP dan WTP DPP =4; WDP=3; TW=2; TMP=1. Kedua. Variabel independen. Variabel independen dalam penelitian ini adalah sebagai berikut.

Pertama. Ukuran Pemerintah Daerah (SIZE). Ukuran perusahaan dapat dinilai melalui total penjualan, jumlah karyawan, total aset yang dimiliki, dan lain-lain. Peneliatian ini mengunakan total aset dalam satuan moneter (Setyaningrum, 2012; Nuraeni dan Martani, 2012; Suharjanto dan Yuliningtyas, 2011) yang tercantum dalam neraca LKPD tahun 2012 dan 2013 audited.

Kedua. Tingkat ketergantungan daerah kepada pusat (DEPEND). Komponen pendapatan daerah terdiri dari pendapatan asli daerah, dan dana transfer. Dana transfer dari pemerintah pusat bertujuan untuk mendukung pelayanan pemerintah daerah kepada masyarakat. Pemerintah daerah yang kemampuan pendapatan asli daerahnya tinggi maka dana bantuan dari pusat akan kecil begitu juga sebaliknya. Pemerintah daerah yang tingkat ketergantungannya masih tinggi pada pusat akan cenderung patuh pada peraturan perundang-undangan mengenai pengelolaan keuangan. Tingkat ketergantungan pemerintah daerah ke pemerintah pusat dapat dilihat dari rasio perbandingan Dana Alokasi Umum (DAU) terhadap total pendapatan. Ukuran tingkat ketergantungan pemerintah daerah kepada pemerintah pusat dalam penelitian ini menggunakan rumus:

$$
\begin{aligned}
& \text { Dana Alokasi Umum } \quad \text { x } 100 \% \\
& \text { Total Pendapatan }
\end{aligned}
$$

Ketiga. Tingkat Kekayaan (WEALTH). Tingkat kekayaan dari pemerintah daerah dapat dilihat dari pendapatan asli daerah. Pendapatan asli daerah adalah pendapatan pemerintah daerah yang berasal dari potensi masing-masing daerah. Potensi setiap pemerintah daerah berbeda-beda semakin baik pengelolaan potensi tersebut maka pendapatan akan semakin tinggi. Pendapatan Asli Daerah menggambarkan tingkat kekayaan daerah. Tingkat kekayaan dalam penelitian ini mengacu pada penelitian Mustikarini dan Fitriasari (2012); Marfiana dan Kuniasih (2013); dan Sumardjo (2010) yang menggunakan realisasi PAD dalam satuan moneter.

Keempat. Realisasi Belanja (EXPEND). Pemerintah daerah melakukan pelayanan kepada masyarakat melalui program dan kegiatan yang telah direncanakan. Program dan kegiatan tersebut diuraikan melalui belanja-belanja yang bertujuan untuk mencapai outcome dari program dan kegiatan tersebut. Belanja-belanja tersebut dapat berupa belanja pegawai, belanja barang dan jasa, dan belanja modal. Penelitian ini menggunakan realisasi total belanja yang terdiri dari belanja pegawai, barang jasa, dan modal yang diukur dalam satuan moneter berdasarkan penelitian Mustikarini dan Fitriasari (2012) dan Marfiana dan Kurniasih (2013).

Kelima. Tindaklanjut Temuan Audit (TIND). Pemeriksaan oleh auditor pada umumnya menghasilkan rekomendasi bagi auditee. Rekomendasi tersebut bertujuan untuk memperbaiki kelemahan-kelamahan sistem pada organisasi auditee. Rekomendasi yang dikeluarkan oleh auditor harus ditindaklanjuti oleh auditee sesuai dengan rekomendasi yang diberikan oleh auditor. Tindaklanjut tersebut dipantau agar sesuai rekomendasi yang diberikan oleh auditor. Tindak lanjut dalam penelitian ini berdasarkan penelitian Arifianti dkk. (2013), yaitu rasio antara tindak lanjut yang sesuai rekomendasi dibandingkan dengan jumlah rekomendasi. 
Keenam. Tingkat Pendidikan (EDUC). Pendidikan adalah hal sangat berpengaruh bagi setiap individu. Pendidikan berkaitan dengan tingkat kognitif individu. Bagi kepala daerah sebagai pemimpin daerah, tingkat pendidikan akan membantu dalam pengambilan keputusan untuk kemajuan daerah. Tingkat pendidikan kepala daerah berdasarkan penelitian Seeba dkk. (2009) dengan modifikasi sebagai berikut, yaitu 1 untuk tingkat pendidikan di bawah S1, 2 untuk tingkat pendidikan S1, dan 3 untuk tingkat pendidikan di atas S1.

Ketujuh. Umur (AGE). Umur pada umumnya merupakan ukuran tingkat kedewasaan seseorang. Seseorang yang lebih berumur cenderung lebih berhati-hati dalam mengambil keputusan dari pada yang lebih muda. Umur yang lebih muda cenderung menyukai tantangan, suka berinovasi, dan lebih bersemangat. Pada penelitian ini umur yang digunakan adalah umur biologis kepala daerah dalam tahun sampai dengan tahun LKPD. Pengukuran ini berdasarkan pada penelitian Seeba dkk. (2009)

Kedelapan. Masa Kerja atau Pengalaman (TENURE). Masa kerja menurut Seeba dkk. (2009) dapat didefinisikan sebagai waktu kerja seseorang pada organisasi tempat seesorang bekerja. Pada penelitian ini, masa kerja atau pengalaman adalah lamanya seorang kepala daerah dalam menjabat sebagai kepala daerah sampai dengan tahun LKPD berakhir. Masa kerja di ukur dalam satuan tahun.

Metode Analisis Data. Penelitian ini analisis data yang digunakan Pada penelitian ini analisis data yang digunakan adalah analisis deskriptif, binomial logistic regression (BLR), dan ordinal logistic regression (MLR). Teknik analisis yang digunakan adalah analisis deskriptif, uji overall fit model, uji nilai goodness of fit test, uji Nagelkerke $\mathrm{R}^{2}$, uji likelihood ratio.

Persamaan Regresi dari penelitian ini adalah

$$
\begin{aligned}
& \frac{\operatorname{Ln} \mathrm{p}}{\mathrm{p}-1}=\alpha 0+\alpha 1 \mathrm{SIZE}+\alpha \text { 2DEPEND }+\alpha 3 \text { WEALTH }+\alpha 4 \text { EXPEND }+\alpha \text { 5TIND } \\
& +\alpha 6 \text { EDUC }+\alpha 7 \text { AGE }+\alpha 8 \text { TENURE }
\end{aligned}
$$

\section{HASIL DAN PEMBAHASAN}

Penelitian ini menggunakan data sekunder yang berasal dari LKPD 2012 dan 2013, buku profile kepala daerah dan website bpk. Sampel yang didapat sebesar 737 buah dengan rincian sebagai berikut ini.

Tabel 1. Pemilihan Sampel

\begin{tabular}{lll}
\hline No & Keterangan & Jumlah \\
\hline 1 & LKPD Audited Tahun 2012 dan 2013 & 912 \\
2 & Data LKPD yang tidak ada dalam sumber data peneliti & 140 \\
3 & Data Kepala Daerah yang tidak lengkap & 39 \\
4 & Jumlah Sampel & 737 \\
\hline
\end{tabular}

Analisis deskriptif. Analisis dekriptif memberikan gambaran umum mengenai data dan penyebaran data yang digunakan dalam penelitian ini. Penggambaran data adalah nilai rata-rata yang akan menggambarkan data penelitian ini. Berikut ini adalah tabel statistik deskriptif data pelitian ini. 
Tabel 2. Statistik Deskriptif Variabel Size, Depend, Wealth, Exp, Tind, Age, Tenure

\begin{tabular}{lrrrr}
\hline Variabel & \multicolumn{1}{c}{ Mean } & \multicolumn{1}{c}{ Max } & \multicolumn{1}{c}{ Min } & \multicolumn{1}{c}{ Std. Deviation } \\
\hline Size & 3.954 .534 .744 .506 & 405.660 .082 .519 .504 & 336.148 .648 .762 & 20.807 .486 .177 .487 \\
Depend & 58,24 & 100 & 1 & 17,64 \\
Wealth & 278.519 .386 .844 & 26.852 .192 .452 .636 & 3.235 .747 .159 & 1.495 .361 .412 .567 \\
Exp & 1.227 .166 .521 .677 & 38.301 .502 .396 .759$, & 295.308 .486 .309 & 2.135 .261 .668 .344 \\
Tind & 33,38 & 100 & 0 & 28,59 \\
Age & 52,12 & 77 & 27 & 7,73 \\
Tenure & 1,87 & 3,9 & 0,1 & 1,15 \\
\hline
\end{tabular}

Tabel 3. Statistik Deskriptif Variabel Opini

\begin{tabular}{lrr}
\hline \multicolumn{1}{c}{ Variabel } & Frekuensi & Persentase \\
\hline Opini WTP/WTP DPP & 230 & $31,2 \%$ \\
Opini WDP & 453 & $61,5 \%$ \\
Opini TW & 10 & $1,4 \%$ \\
Opini TMP & 44 & $6 \%$ \\
\hline
\end{tabular}

Tabel 4. Statistik Deskriptif Variabel Educ

\begin{tabular}{|c|c|c|}
\hline Variabel & Frekuensi & Persentase \\
\hline Diatas S1 & 349 & $47,4 \%$ \\
\hline S1 & 247 & $33,5 \%$ \\
\hline Dibawah S1 & 141 & $19,1 \%$ \\
\hline
\end{tabular}

Berdasarkan Tabel 2 di atas menunjukan bahwa, nilai rata-rata total aset pemerintah daerah adalah 3.954.534.744.506, rata-rata tingkat ketergantungan pemerintah daerah kepada pemerintah pusat adalah sebesar 58,24\%, rata-rata PAD pemerintah daerah tahun 2012 dan 2013 adalah sebesar 278.519.386.844, tingkat realisasi belanja 1.227.166.521.677. Tindak lanjut hasil temuan pada pemerintah daerah adalah 33,38 \% dari total rekomendasi yang diberikan oleh BPK. Rata-rata umur kepala daerah di Indonesia pada yang menjabat pada tahun 2012 dan 2013 adalah 52 tahun dan rata-rata masa kerja kepala daerah adalah 1,8 tahun.

Berdasarkan Tabel 3 di atas menunjukkan bahwa pada tahun 2012 dan 2013 opini yang didapat oleh pemerintah daerah adalah opini WDP yaitu sebesar 453 LKPD atau sebesar 61,5 \%. Berdasarkan Tabel 4 di atas menunjukkan bahwa tingkat pendidikan kepala daerah yang terbanyak adalah di atas sarjana yaitu sebesar 349 orang atau 47,4 \%.

Binomial Logistic Regression. (1) Uji -2 Log Likelihood (-2LogL). Uji likelihood dalam penelitian ini diperoleh nilai -2LogL adalah sebesar 69,144 dengan nilai signifikansi adalah 0,000. Hal ini berarti penambahan variabel independen yaitu size, depend, wealth, expend, tind, educ,age, dan tenure ke dalam model penelitian dapat memperbaiki model fit. (2) Uji Nilai Hosmer and Lemeshow's Goodness of Fit Test. Hasil penelitian ini nilai Hosmer and Lemeshow's Goodness of Fit Test adalah 0,443 yang berarti bahwa nilai tersebut lebih besar dari 0,05 sehingga model baik atau dapat diterima. Dengan demikian, maka model dapat digunakan untuk memprediksi observasi dalam penelitian. (3) Uji Nagelkerke $\mathrm{R}^{2}$. Pada penelitian ini nilai Nagelkerke $\mathrm{R}^{2}$ adalah sebesar 0,126 yang berarti bahwa variabilitas variabel dependen yang dapat dijelaskan oleh variabel dependen adalah 
12,6 \% sedangkan sisanya 87,8 \% dijelaskan oleh variabel-variabel lain di luar penelitian. (3) Uji Estimasi Parameter. Uji ini dapat dilihat dari tampilan outputvariable in equation yang dapat dilihat dalam Tabel 5 berikut ini.

Tabel 5. Hasil Uji Binomial Logistic Regression

\begin{tabular}{lllllll}
\hline \multicolumn{1}{c}{ Variabel } & \multicolumn{1}{c}{ B } & & S.E & \multicolumn{1}{c}{ Wald } & Df & \multicolumn{1}{c}{ Sig } \\
\hline LnSize & 0,445 & 0,254 & 3,066 & 1 & $0,080^{*}$ \\
Depend & $-0,016$ & 0,008 & 3,889 & 1 & $0,049^{* *}$ \\
LnWealth & 0,346 & 0,137 & 6,439 & 1 & $0,011^{* *}$ \\
LnExpend & $-0,876$ & 0,359 & 5,949 & 1 & $0,015^{* *}$ \\
Tind & 0,014 & 0,003 & 21,036 & 1 & $0,000^{* * *}$ \\
Educ & $-0,079$ & 0,113 & 0,492 & 1 & 0,483 \\
Age & 0,001 & 0,011 & 0,003 & 1 & 0,957 \\
Tenure & 0,257 & 0,079 & 10,670 & 1 & $0,001^{* * *}$ \\
Constant & $-23,468$ & 6,828 & 11,813 & 1 & 0,001 \\
\hline
\end{tabular}

LnSize: ukuran pemerintah daerah; Depend: ketergantungan pemerintah daerah kepada pemerintah pusat; LnWealth: tingkat kekayaan pemerintah daerah; LnExpend: tingkat belanja pemerintah daerah; Tind: tindak lanjut temuan audit; Educ: tingkat pendidikan kepala daerah; Age: umur kepala daerah; Tenure: masa kerja kepala daerah

$* * *$ signifikan pada level $\alpha=1 \%$

$* *$ signifikan pada level $\alpha=5 \%$

* signifikan pada level $\alpha=10 \%$

Berdasarkan hasil di atas maka diperoleh persamaan sebagai berikut ini.

Opini $=-23,468+0,445$ LnSIZE - 0,016DEPEND + 0,346WLnWEALTH 0,876EXPEND + 0,014TIND - 0,079 EDUC + 0,001AGE +0,257 TENURE

Variabel independen yang mempengaruhi variabel dependen pada level signifikan $1 \%$ adalah variabel Tind (tindak lanjut temuan audit) dan Tenure (masa jabatan). Variabel independen yang mempengaruhi variabel dependen pada level signifikan $5 \%$ adalah LnSize (ukuran pemerintah daerah), depend (tingkat ketergantungan pemerintah pusat terhadap pemerintah daerah), LnWealth (kekayaan daerah), LnExp (belanja daerah).

LnSize, lnwealth, tind, dan tenure signifikan serta mempunyai mempunyai koefisien positif sehingga H1, H3, H5, H8 dapat diterima. Variabel depend walaupun signifikan namun mempunyai koefisien negatif sehingga $\mathrm{H} 2$ tidak diterima. Lnexp mempunyai nilai signifikan dan koefisien negatif sehingga $\mathrm{H} 4$ dapat diterima.

Ordinal Logistic Regression. (1) Uji -2 Log Likelihood (-2LogL). Uji likelihood dalam penelitian ini diperoleh nilai -2LogL adalah sebesar 108,203 dengan nilai signifikansi adalah 0,000. Hal ini berarti penambahan variabel independen yaitu size, depend, wealth, expend, tind, educ,age, dan tenure ke dalam model penelitian dapat memperbaiki model fit.(2) Uji Nilai Goodness of Fit Test. Pada penelitian ini nilai goodness fit adalah sebesar 1202,437 dengan nilai probabilitas sebesar 1,00 yang nilainya di atas 0,05. Hal tersebut dapat disimpulkan bahwa model dalam penelitian ini adalah fit dan model dapat diterima sehingga dapat digunakan untuk memprediksi observasi dalam penelitian. (3) Uji Nagelkerke $\mathrm{R}^{2}$. Uji Nagelkerke $\mathrm{R}^{2}$ merupakan modifikasi dari koefisien Cox dan Snell untuk memastikan bahwa nilainya variasi antara no sampai dengan 1 . Nilai Nagelkerke $\mathrm{R}^{2}$ dapat diintepretasikan seperi $\mathrm{R}^{2}$ multiple regression. Dalam penelitian ini, nilai uji 
Nagelkerke $\mathrm{R}^{2}$ adalah sebesar $16,4 \%$. Hal ini berarti bahwa variabilitas variabel independen yang dapat menjelaskan variabel dependen adalah sebesar 16,4 \%, sedangkan sisanya sebesar 83,6 \% dijelaskan oleh variabel-variabel lain di luar model. (4) Uji Parameter Estimates. Uji ini terdiri atas dua yaitu theshold yaitu merupakan konstan atau intercept dan location yang merupakan slope dari prediktor variabel (Latan 2014: hal. 231)

Tabel 6. Hasil Pengujian Ordinal Logistic Regression

\begin{tabular}{|c|c|c|c|c|c|c|}
\hline & & Estimate & Std. Error & Wald & $\mathrm{df}$ & Sig. \\
\hline \multirow[t]{3}{*}{ Threshold } & {$[$ Opini $=1]$} & $-6,843$ & 6,062 & 1,274 & 1 & 0,259 \\
\hline & {$[$ Opini = 2] } & $-6,612$ & 6,062 & 1,190 & 1 & 0,275 \\
\hline & {$[$ Opini = 3] } & $-2,932$ & 6,056 & 0,234 & 1 & 0,628 \\
\hline \multirow[t]{10}{*}{ Location } & LnSize & 0,347 & 0,239 & 2,121 & 1 & 0,145 \\
\hline & Depend & $-0,017$ & 0,008 & 4,861 & 1 & $0,027 * *$ \\
\hline & LNWealth & 0,466 & 0,126 & 13,638 & 1 & $0,000 * * *$ \\
\hline & LNExpend & $-0,923$ & 0,333 & 7,668 & 1 & $0,006^{* * *}$ \\
\hline & Tind & 0,015 & 0,003 & 27,449 & 1 & $0,000 * * *$ \\
\hline & Age & $-0,002$ & 0,010 & 0,022 & 1 & 0,883 \\
\hline & Tenure & 0,268 & 0,071 & 14,060 & 1 & $0,000^{* * *}$ \\
\hline & [Educ=1] & 0,217 & 0,216 & 1,007 & 1 & 0,316 \\
\hline & {$[$ Educ $=2]$} & 0,470 & 0,178 & 6,989 & 1 & $0,008 * * *$ \\
\hline & {$[$ Educ $=3]$} & $0^{\mathrm{a}}$ & ㅇ & & 0 & \\
\hline
\end{tabular}

LnSize: ukuran pemerintah daerah; Depend: ketergantungan pemerintah daerah kepada pemerintah pusat; LnWealth: tingkat kekayaan pemerintah daerah; LnExpend: tingkat belanja pemerintah daerah; Tind: tindak lanjut temuan audit; Educ: tingkat pendidikan kepala daerah; Age: umur kepala daerah; Tenure: masa kerja kepala daerah

$* * *$ signifikan pada level $\alpha=1 \%$

** signifikan pada level $\alpha=5 \%$

* signifikan pada level $\alpha=10 \%$

Berdasarkan hasil analisis regresi logistik ordinal yang dilakukan menemukan bahwa variabel independen yang memiliki level signifikansi $\alpha=1 \%$ adalah lnwealth, $\ln$ expend,tind, tenure, dan educ. Variabel independen yang memiliki tingkat signifikansi $\alpha=$ 5 \%adalah depend. Hipotesis yang dapat diterima dengan menggunakan uji ini adalah $\mathrm{H} 3$, H4, H5, H6, dan H8. Walaupun H2 mempunyai nilai yang signifikan namun nilai koefisiennya negatif sehingga $\mathrm{H} 2$ ditolak.

Uji Parallel Lines. Uji ini digunakan untuk menguji asumsi proporsional odds di dalam regresi ordinal. Nilai parallel lines yang tidak signifikan $>0,05$ menunjukkan kalau asumsi ini terpenuhi. Hasil penelitian ini menunjukkan bahwa niali dari uji paralles lines sebesar 0,000 sehingga asumsi ini tidak terpenuhi. Apabila asumsi ini tidak terpenuhi maka model tidak cocok sehingga perlu dilakukan permodelan kembali. Ada beberapa alternatif yang dapat dilakukan antara lain sebagai berikut ini: (a) Mengganti dengan multinomial regression; (b) Menghapus beberapa indikator yang dapat menyebabkan tidak signifikan; (c) Menggunakan jumlah sampel yang lebih besar. 
Berdasarkan hasil analisis regresi logistik yang dilakukan maka pengujian hipotesis dapat disajikan sebagai berikut ini.

Ukuran Pemerintah Daerah yang besar kemungkinan mendapatkan opini yang lebih baik dari BPK. Pada pengujian binomial regresi logistik ukuran pemerintah daerah mempunyai nilai signifikansi 0,080 dan berkoefisien positif sehingga $\mathrm{H} 1$ dapat diterima. Hal ini berarti semakin besar nilai aset yang dimiliki pemerintah daerah kemungkinan akan mendapatkan opini yang lebih baik atau WTP. Penelitian ini mendukung penelitian DeAngelo (1981); Deis dan Giroux (1992); Setyaningrum (2012) bahwa pemerintah daerah yang mempunyai aset besar akan menyajikan laporan keuangan yang jauh dari salah saji. Aset yang besar merupakan sumber daya yang baik dalam menjalankan organsasi. Menurut Doyle dkk. (2005); Petrovits dkk. (2011); dan Zaelani (2010), Nuraeni dan Martani 2012) menyatakan bahwa organisasi dengan aset yang besar mempunyai sistem pengendalian intern yang kuat. Sistem pengendalian intern yang kuat menghasilkan laporan keuangan yang andal dan reliabel sehingga opini audit akan menjadi lebih baik.

Namun, pada pengujian dengan menggunakan ordinal logistic regression secara keseluruhan ukuran pemerintah daerah nilainya tidak signifikan terhadap kemungkinan perolehan opini audit yaitu dengan nilai signifikansi sebesar 0,145.

Tingkat ketergantungan pemerintah daerah terhadap pemerintah pusat yang tinggi kemungkinan mendapatkan opini yang lebih baik dari BPK. Tingkat ketergantungan pemerintah daerah mempunyai nilai signifikansi 0,049 dan mempunyai koefisien negatif pada pengujian binomial logistic regression begitu juga dengan pengujian dengan menggunakan ordinal logistic regression tingkat ketergantungan mempunyai nilai signifikan sebesar 0,027 . Oleh karena itu, H2 tidak diterima. Penelitian ini tidak berhasil mendukung penelitian (Susbiyani dkk. 2014; Mustikarini dan Fitriasari 2012; Martani dan Lestiani 2012; Robin dan Austin 1986) yang menyatakan bahwa semakin tinggi tingkat ketergantungan pemerintah daerah kepada pemerintah pusat maka pemerintah daerah akan lebih mentaati peraturan perundang-undangan yang berlaku. Hal ini menunjukkan bahwa pengawasan pemerintah pusat terhadap dana-dana yang diberikan kepada pemerintah daerah kurang dimonitoring dan dievaluasi dengan memadai.

Tingkat kekayaan pemerintah daerah yang tinggi kemungkinan mendapatkan opini yang lebih baik dari BPK. Tingkat kekayaan pemerintah daerah mempunyai tingkat signifikan sebesar 0,11 yang berarti di bawah 0,05 dan mempunyai korelasi positif sehingga H3 dalam penelitian ini dapat diterima. Hal ini berarti bahwa semakin besar pendapatan maka semakin besar kemungkinan mendapatkan opini yang lebih baik atau opini WTP. Pengujian dengan ordinal logistic regression juga menunjukkan hasil yang konsisten dengan tingkat signifikasi sebesar 0,000. Hasil ini mendukung penelitian yang menyatakan bahwa kekayaan pemerintah daerah mempunyai pengaruh positif pada pengungkapan LKPD (Laswad dkk., 2005; Setyaningrum dan Syafitri, 2012) kinerja pemerintah daerah (Mustikarini dan Fitriasari, 2012). Pendapatan asli daerah yang besar mencerminkan bahwa pemerintah dituntut untuk mempertanggungjawabkan dan mengungkapkan PAD oleh para stakeholder khususnya penyumbang pendapatan. Selain itu, pemerintah daerah dapat memperkecil potensi-potensi kehilangan pendapatan yang menyebabkan kerugian negara. 
Tingkat belanja pemerintah daerah yang tinggi kemungkinan mendapatkan opini yang lebih buruk dari BPK. Variabel belanja pada uji binomial logistic regression mempunyai nilai signifikansi sebesar 0,015 dan berkorelasi negatif maka $\mathrm{H} 4$ dalam penelitian ini dapat diterima. Konsisten dengan hasil di atas pada uji dengan menggunakan ordinal logistic regression nilai signifikansinya sebesar 0,006 . Penelitian ini mendukung penelitian yang menyatakan bahwa belanja berpengaruh negatif terhadap opini audit (Nurdiono, 2014) dan kinerja pemerintah daerah (Mustikarini dan Fitriasari, 2012). Belanja pemerintah yang besar mencerminkan kegiatan yang komplek dan rumit dan jika sistem pengendalian intern pengelolaan belanja tidak optimal maka akan terjadi banyaknya penyimpangan belanja.

Tindak lanjut temuan audit yang tinggi kemungkinan mendapatkan opini yang lebih baik dari BPK. Tindak lanjut temuan audit mempunyai nilai signifikansi 0,000 dan mempunyai korelasi positif yang berarti bahwa $\mathrm{H} 5$ dalam penelitian ini dapat diterima. Pada pengujian dengan menggunakan ordinal logistic regression menunjukkan hasil yang konsisten dengan nilai signifikansi sebesar 0,000. Hal ini berarti bahwa, pemerintah daerah yang presentase tindak lanjut temuan audit yang sesuai rekomendasi mempunyai kemungkinan akan mendapatkan opini yang lebih baik atau WTP. Hal ini mendukung penelitian Arifianti dkk. (2013) bahwa tindak lanjut audit berpengaruh pada kinerja pemerintah daerah dan penelitian Astriani (2014) menyatakan bahwa tindak lanjut temuan audit BPK mempunyai pengaruh yang signifikan terhadap kualitas audit pada LKPD Kabupaten/Kota Propinsi Jawa Barat. Tindak lanjut temuan audit yang sesuai dengan rekomendasi dapat meningkatkan good governance sehingga kemungkinan mendapatkan opini yang lebi baik juga tinggi.

Tingkat pendidikan kepala daerah yang tinggi kemungkinan mendapatkan opini yang lebih baik dari BPK. Tingkat pendidikan kepala daerah mempunyai tingkat signifikansi 0,483 dan berkorelasi negatif sehingga $\mathrm{H} 6$ dalam penelitian ini tidak dapat diterima. Tingkat pendidikan kepala daerah diharapkan berpengaruh terhadap pilihan strategis kepala daerah dalam mencapai visi misi daerah. Tingkat pendidikan kepala daerah dapat mencerminkan tingkat pengetahuan dan skill kepala daerah.

Namun, pada pengujian dengan ordinal logistic regression tingkat pendidikan mempunyai kemungkinan yang signifikan berpengaruh terhadap perolehan opini audit dan mempunyai korelasi positif dengan nilai signifikansi sebesar 0,008. Berdasarkan uji tersebut maka dapat diartikan bahwa tingkat pendidikan kepala daerah dengan tingkat pendidikan S1 atau sarjana dapat mempengaruhi kemungkinan perolehan audit yang lebih baik.

Umur kepala daerah yang besar kemungkinan mendapatkan opini yang lebih buruk dari BPK. Umur dari kepala daerah mempunyai tingkat signifikansi sebesar 0,957 yang berarti jauh di atas 0,05 dan berkorelasi positif maka $\mathrm{H7}$ dalam penelitian ini tidak diterima. Pada uji ordinal logistic regression umur dari kepala daerah juga tidak signifikan dengan nilai signifikansi 0,883. Hal ini mendukung penelitian Seeba dkk. (2009) bahwa umur tidak signifikan dengan kinerja perusahaan. Menurut upper echelon theory seorang top manager yang berusia lebih muda akan lebih mempunyai inovasi yang tinggi dalam meningkatkan kinerja organisasi. Umur kepala daerah yang lebih muda diharapkan mencerminkan semangat yang tinggi, mengambil resiko yang tinggi dalam mengambil keputusan strategis bagi organisasi. 
Masa kerja kepala daerah yang panjang kemungkinan mendapatkan opini yang lebih baik dari BPK. Masa kerja kepala daerah mempunyai tingkat signifikansi 0,001 dan mempunyai koefisien positif yang berarti jauh di bawah 0,05 sehingga H8 dapat diterima. Pada pengujian dengan menggunakan ordinal logistic regression menunjukkan nilai signifikansi sebesar 0,000 Penelitian ini mendukung penelitian Hambrick dan Manson, 1984, Seeba dkk., 2009, Qin, 2012, Hutzschenreuter dan Horstkotte, 2012, dan Damanpour dan Schneider, 2008 yang menyatakan bahwa pengalaman dalam berkarir diharapkan akan mempengaruhi top manager dalam pengambilan keputusan.

\section{PENUTUP}

Kesimpulan. Berdasarkan hasil pengujian dengan menggunakan binomial logistic regresion, hipotesis yang dapat diterima adalah $\mathrm{H} 1, \mathrm{H} 3, \mathrm{H} 4, \mathrm{H} 5, \mathrm{H} 8$, sedangkan, H2 walaupun mempunyai nilai pengaruh yang signifikan namun mempunyai koefisien negatif sehingga tidak sesuai dengan hipotesa. Berdasarkan hasil pengujian dengan menggunakan ordinal logistic regresion hipotesis yang dapat diterima adalah H3,H4, H5, H6, H8, sedangkan $\mathrm{H} 2$ walaupun, mempunyai nilai pengaruh yang signifikan namun mempunyai koefisien negatif sehingga tidak sesuai dengan hipotesa.

Berdasarkan analisis data yang telah dilakukan dapat disimpulkan bahwa variabel independen yang mempunyai nilai signifikan dari dua pengujian adalah tingkat ketergantungan pemerintah daerah kepada pemerintah pusat, tingkat kekayaan daerah, tingkat realisasi belanja, tindak lanjut temuan audit, dan masa kerja kepala daerah. Variabel ukuran pemerintah daerah mempunyai pengaruh yang signifikan pada pengujian dengan menggunakan binomial logistic regresion dan tingkat pendidikan kepala daerah mempunyai pengaruh yang signifikan pada uji ordinal logistic regresion. Hasil dari dua pengujian yang menggunakan regresi logistik di atas menunjukkan hasil yang tidak konsisten. Hal ini merupakan tantangan bagi peneliti selanjutnya untuk melakukan penelitian mengenai faktor-faktor yang kemungkinan berpengaruh terhadap pemberian opini audit oleh BPK.

Keterbatasan penelitian ini adalah sampel yang digunakan dalam penelitian ini terbatas pada LKPD tahun 2012 dan 2013 saja dan sumber data LKPD tahun 2012 dan 2013 yang dimiliki peneliti tidak lengkap. Karakteristik pemerintah daerah terbatas pada daerah yang melakukan pilkada dari tahun 2010 sampai dengan 2013. Karakteristik kepala daerah dalam penelitian ini hanya terdiri dari tingkat pendidikan, umur, dan masa kerja sedangkan latar belakang pendidikan, pengalaman kepala daerah yang dilihat dari periode jabatan belum dimasukkan dalam penelitian ini. Variabel tindak lanjut temuan audit terbatas pada jumlah tindak lanjut yang sesuai rekomendasi tanpa menilai jumlah nilai tindak lanjut temuan audit. Pengujian dalam penelitian ini menggunakan dua regresi logistik, yaitu binomial dan ordinal logistic regresion, namun hasil keduanya tidak konsisten.

Saran. Berdasarkan keterbatasan di atas maka saran untuk penelitian selanjutnya adalah mencari sumber data yang lebih banyak lagi sesuai dengan IHPS yang dikeluarkan oleh BPK dan profil kepala daerah yang lebih lengkap. Selain itu untuk mengetahui pengaruh karakteristik kepala daerah terhadap opini audit sebaiknya menambah variabel pada karakteristik kepala daerah. Pada variabel tindak lanjut temuan audit disarankan juga menggunakan jumlah nominal tindak lanjut yang sesuai dengan rekomendasi. Penelitian 
dengan dua uji logistik, yaitu binomial dan ordinal logistic regresion, belum menunjukkan hasil yang konsisten. Oleh karena itu, diharapkan penelitian mendatang menggunakan uji yang berbeda dengan penelitian ini.

\section{DAFTAR RUJUKAN}

Adzani, A.H. dan Martani, D. (2014) "Pengaruh Kesejahteraan Masyarakat, Faktor Politik, dan Ketidakpatuhan Regulasi terhadap Opini Audit Laporan Keuangan Pemerintah Daerah”. Simposium Nasional Akuntansi XVII. Lombok.

Amran, N. A., M. A. M.Yusof, R. Ishak, dan N. Arinin. (2014) Do Characteristics of CEO and Chairman Influence Government Linked Companies Performance? ProcediaSocial and Behavioral Sciences 109: 799-803.

Arfianti H., Payamta, dan Sutaryo. (2013) Pengaruh Pemeriksaaan dan Pengawasan Keuangan Daerah terhadap Kinerja Penyelenggaraaan Pemerintah Daerah (Studi Empiris pada Pemerintah Kabupaten/ Kota di Indonesia). Simposium Nasional Akuntansi XVI. Manado.

Astragina, K. (2013) “Analisis Faktor-Faktor Dibalik Prestasi Akuntabilitas Pemerintah Provinsi Jawa Timur”. Jurnal Akuntansi ejournal.unesa.ac.id. Diakses tanggal 25 Juni 2015.

Astriani D. (2013) "Pengaruh Penyelesaian Temuan Audit Terhadap Kualitas Laporan Keuangan Pemerintah Daerah (Survei pada Badan Pengawasan Keuangan dan Pembangunan (BPKP)”. Skripsi. Fakultas Ekonomi dan Bisnis Program Studi Akuntansi. Universitas Widyatama. Dipublikasikan.

Atyanta, Ramya. (2013) "Analisis Opini BPK atas Laporan Keuangan Pemerintah Daerah (Studi Kasus pada Kabupaten X di Jawa Timur”. Jurnal Ilmiah Mahasiswa FEB, diakses 26 Juni 2015 dari http://JIMFEB.UB.AC.ID.

Badan Pemeriksa Keuangan. (2014) Laporan Hasil Pemeriksaan Semester II Tahun 2014. Diakses tanggal 18 April 2015 dari http: www.bpk.go.id.

Badan Perencanaan Pembangunan Nasional. (2013) Evaluasi Paruh Waktu RPJMN 20102014. Diakses tanggal 1 April 2015 dari http: www.bppn.go.id

Bamber, L.S., J. Jiang, dan I.Y. Wang. (2010) "What's My Style? The Influence of Top Managers on Voluntary Corporate Financial Discousure". The Accounting Review 85(4): 1131-1162.

Bastian, I., (2006) Sistem Akuntansi Sektor Publik. Jakarta: Salemba Empat.

Caramanis, C. dan Spathis, C. (2006) "Auditee and Audit Firm Characteristics as Determinants of Audit Qualifications: Evidance from the Athens Stock Exchange”. Managerial Auditing Journal 21(9): 905-920.

Chang, X., S. Dasgupta, dan G. Hilatry. (2009) “The Effect of Auditor Quality on Financing Decisions”. The Accounting Review 84(4): 1085-1117.

Cohen, S. dan Leventis, S. (2013) Effect of Municipial, Auditing and Political Factors on Audit Delay. Accounting Forum 37: 40-53.

Copley, P. A. (1991) "The Association between Municipial Disclousure Practices and Audit Quality”. Journal of Accountingand Publicy 10: 245-266.

Cullinan, C.P., F. Wang, B. Yang, J. Zhang. (2012) Audit Opinion Improvement and the Timing of Disclousure. Advances in Accounting, Incorporating Advances in International Accounting 28: 333-343. 
Damanpour, F. dan Schneider, M. (2008) "Characteristics of Innovation and Innovation Adoption in Public Organizations: Assessing the Role of Managers". Journal of Public Administration Research and Theory: 495-522.

DeAngelo, L.E. (1981) “Auditor Size and Audit Quality”. Journal of Accounting and Economics 3: 183-199.

Deis, D. R. dan Giroux, G.A. (1992) "Determinants of Audit Quality in Public Sector”. The Accounting Review 67(3): 462-479.

Doyle, J.T., Weili, G., dan Sarah McVay, (2005) Determinants of Weaknesses in Internal Control over Financial Reporting. School Conference at Columbia University AAA Midwest Regional Meeting.

Dwiputrianti, S. (2011) Effectiveness of Public Sector Audit Reports in Indonesia (Preceding and Following Audit Reform). Ph.D Dissertation Dipublikasikan. The Australian National University.

Fernadez, M. C. D., M. R. G. Rodriguez, dan B. Simonetti. (2015) “Top Management Teams Intelectual Capital and Firm Performance”. European Management Journal.

Finkelstein, S. dan Hamrick, D.C. (1990) Top Management Tean Tenure and Organizational Outcomes: The Moderating Role of Managerial Discretion. Administrative Science Quarterly 35(3): 484-503.

Ghozali, Imam. (2006) Aplikasi Analisis Multivariate dengan Program SPSS. Semarang. Badan Penerbit Universitas Diponegoro.

Giroux, G. Dan McLelland, A.J. (2003) "Governance Structures And Accounting At Large Municipalities”. Journal of Accounting and Public Policy 22: 203-230.

Habib, A. (2013) "A Meta Analysis of the Determinants of Modified Audit Opinion Decesions”. Managerial Auditing Journal 28 (3): 184-216.

Halim, A. (2004) Akuntansi Sektor Publik Akuntansi Keuangan Daerah. Edisi Revisi. Jakarta: Salemba Empat.

Halim, A. dan Abdullah, S. (2006) "Hubungan dan Masalah Keagenan di Pemerintah Daerah Sebuah Peluang Penelitian Anggaran dan Akuntansi”. Jurnal Akuntansi Pemerintah 2(1): 53-64.

Hapsari,S.I., Sutaryo, dan I.F. Wijaya. (2013) ”Penentu Jumlah Temuan BPK atas Sistem Pegendalian Intern dan Kepatuhan (Internal Control Compliance Comments) Pemerintah Daerah di Indonesia”. Simposium Nasional Akuntansi XVI. Manado.

Hariadi, E.S., Kamaliah, dan V. Ratnawati. (2015) ”Analisis Pengungkapan (Disclousure) Laporan Keuangan yang Meraih Opini Audit Wajar Tanpa Pengecualian (WTP) Dua Tahun Berturut-turut”. Jurnal Akuntansi 3(2): 184-195.

Hartono, T. (2006) "Evaluasi Penyelesaian Tindak Lanjut Temuan Audit sebagai Unsur Penilaian Kinerja Manajemen Kantor Cabang (Studi Kasus pada Bank BTN)”. Tesis Dipublikasikan. Universitas Diponegoro.

Heriningsih, S. dan Rusherlistyani. (2014 Pengungkapan Laporan Keuangan, Kelemahan SPI, dan Ketaatan pada Perundang-undangan Dianalisis dari Opini Auditor. Seminar Nasional \& Call Paper Akuntansi, Ekonomi, dan Bisnis, SiNAU UPN Veteran.

Heriningsih, S. dan Rusherlistyani. (2013) "Faktor-Faktor yang Mempengaruhi Tingkat Pengungkapan Laporan Keuangan Pemerintah Daerah”. Jurnal Ekonomi dan Bisnis 13(2): 11-19.

Hilmi, A. Z. Dan Martani, D. (2012) Analisis Faktor-Faktor Yang Mempengaruhi Tingkat Pengungkapan Laporan Keuangan Pemerintah Provinsi. Simposium Nasional Akuntansi XV.Banjarmasin. 
Husnatarina, F. dan Halim, A. (2013) "Relationship Between The Type of Auditor Opinions with the Differenc of Local Government Forms in Indonesia". Review of Integrative Business \& Economics Research 2(1): 102-119.

Hutzschenreuter, T. Dan Horstkotte, J. (2013) "Performance Effects of International Expansion Prosesses: the Moderating Role of Top Management Team Experiences”. International Business Review 22: 259-277.

Jensen, M.C. dan Meckling, W. H. (1976) "Theory of the Firm: Managerial Behavior, Agency Cost and Ownership Structure”. Journal of Financial Economics 3: 305360.

Johnson, L.E., S. Lowenson, dan J.L. Reck, S.P. Davies. (2012) "Management Letter Comment: Their Determinants and Their Association with Financial Reporting Quality In Local Government”. Journal Account Public Policy 31: 575-592.

Kawedar, Warsito. (2009) "Opini Audit dan Sistem Pengendalian Intern (Studi Kasus di Kabupaten PWJ Yang Mengalami Penurunan Opini Audit)”. Jurnal Akuntansi dan Auditing 1(6).

Laswad, F., R. Fisher, dan P. Oyelere. (2005) "Determinant of Voluntary Internet Financial Reporting by Local Government Authorities”. Journal of Accounting and Public Policy 24: 101-121.

Latan, H. (2014) Aplikasi Analissi Data Statistik Untuk Ilmu Sosial Sains dengan IBM SPPS. Bandung: Alfabeta.

Marfiana, N., dan Kurniasih, L. (2013) "Pengaruh Karakteristik Pemerintah Daerah dan Hasil Pemeriksaan Audit BPK terhadap Kinerja Keuangan Pemerintah Daerah Kabupaten/Kota”. Journal \& Proceeding FEB Unsoed 3(1).

Martani, D. dan Lestiani, A. (2012) "Disclousure in Local Government Financial Statement: the Case of Indonesia”. Global Review of Accounting and Finance 3(1): 67-84.

Michel, J.G. dan Hambrick, D.C. (1992) “Diversification Posyure and Top Management Team Characteristics”. Academy of Management Journal 35(1): 9-37.

Milal, A.Z. (2013) "Makna Opini WTP Bagi Kementrian /Lembaga (Studi Kasus Pada Kementrian Sosial”. Jurnal Ilmiah Mahasiswa FEB, diakses tanggal 26 Juni 2015 dari http://jimfeb.ub.ac.id.

Mustikarini, W., A., dan Fitriasari, D. (2012) "Pengaruh Karakteristik Pemerintah Daerah dan Temuan Audit BPK Terhadap Kinerja Pemerintah Daerah Kabupaten/Kota di Indonesia Tahun Anggaran 2007”. Simposium Nasional Akuntansi XV. Banjarmasin.

Nordiawan, D. dan Hertianti, A. (2010) Akuntansi Sektor Publik. Jakarta. Salemba Empat Edisi 2.

Nuraeni dan Martani, D. (2012) The Impact Of Local Governments Characteristics toward Their Audit Quality for Financial Reports of 2008-2009, 3rd International Conference on Business And Economic Research (3rd ICBER 2012).

Nurdiono. (2014) Analisis Hasil Audit Laporan Keuangan Pemerintah Daerah Seluruh Indonesia. Disertasi Dipublikasikan. Universitas Gadjah Mada.

Patrick, P. A. (2007) The Determinant of Organizational Inovativeness: The Adoption of GASB 34 in Pennsylvania Local Government. Ph.D Dissertation Dipublikasikan. Pennsylvania. The Pennsylvania State University.

Peraturan Badan Pemeriksa Keuangan Nomor 01 Tahun 2007 tentang Standar Pemeriksaan Keuangan Negara. 
Petrovits, C., C. Shakespeare, dan A. Shih. (2011) The Causes and Consequences of Internal Control Problems in Nonprofit Organizations. The Accounting Review 86 (1): 325-357.

Prasetya, A. (2014) Karakteristik Kepala Daerah dan Kinerja Penyelenggaraan Pemerintah Daerah. Tesis Tidak Dipublikasikan. FEB Universitas Sebelas Maret Surakarta.

Purba, C.B. (2015) Efektivitas Tindak Lanjut Hasil Pemeriksaan BPK atas Laporan Keuangan Pemerintah Daerah di Kalimantan Barat, Kalimantan Tengah, dan Kalimantan Timur. Diakses tanggal 16 April 2015. http:www.e-learning.stmi.ac.ic.

Pusat Bahasa Departemen Pendidikan Nasional. (2008) Kamus Bahasa Indonesia. Departemen Pendidikan Nasional.

Qin, B. (2012) The Influence of Firm and Executive Characteristics on Performancevested Stock Option Grants. International Business Review 21: 906-928.

Robbins, W.A. dan Austin, K.R. (1986) Determinant Quality in Governmental Financial Reports: An Assessment of the Appropriateness of a Compound Measure. Journal of Accounting Research 24 (2): 412-421.

Rochmatullah, M.R. (2014) Determinan Pengalokasian Belanja Bantuan Sosial Pada Pemerintah Daerah Tingkat II di Indonesia. Tesis Tidak Dipublikasikan. Universitas Sebelas Maret Surakarta.

Sanchez, I. M.G., Aceituno, J. V. F., dan Dominguez, L. D. (2013) "Determinants of Corporate Social Disclousure in Spanish Local Governments". Journal of Cleaner Production 39: 60-72.

Sari, Diana. (2013) Pengaruh Sistem Pengendalian Intern Pemerintah, Implementasi Standar Akuntansi Pemerintah, Penyelesaian Temuan Audit Terhadap Penerapan Prinsip-Prinsip Tata Kelola Pemerintahan yang Baik (Penelitian Pada Pemerintah Daerah Di Provinsi Jawa Barat dan Banten). Simposium Nasional Akuntansi XVI. Manado.

Scott, William R. (2003) Financial Accounting Theory. 3th Ed.New Jersey: Prentice Hall International, Inc.

Sebaa, A., J. Wallace, dan N. Cornelius. (2009) Managerial Characteristics, Strategy and Performance in Local Government. Measuring Business Excellence 13(4): 12-21.

Sekaran, U. dan Bougie, R. (2013) Research Methods for Business: A Skill-Buiding Approach. New Jersey:John Wiley \& Son Ltd.

Setyaningrum, D. (2012) Analisis Faktor-Faktor yang Mempengaruhi Kualitas Audit $B P K-R I)$. Simposium Nasional Akuntansi XV. Banjarmasin.

Setyaningrum, D. dan Syafitri, F. (2012) Analisis Pengaruh Karakteristik Pemerintah Daerah Terhadap Tingkat Pengungkapan Laporan Keuangan. Jurnal Akuntansi dan Keuangan Indonesia 9 (2): 154-170.

Sittipongpanich, T., dan Palsiri, P. (2015) "Do CEO and Borad Characteristics Matter? A Study of Thai Family Firms”. Journal of Familiy Business Strategy.

Spathis, C., M. Doumpos, C. Zopounidis. (2003) “Using Client Performance Measures To Identify Pre Engagement Factors Associated With Qualified Audit Reports in Greece”. The International Journal of Accounting 38: 267-284.

Sudarsana, H. S. (2013) Pengaruh Karateristik Pemerintah Daerah dan Temuan Audit BPK terhadap Kinerja Pemerintah Daerah (Studi pada Pemerintah Kabupaten/Kota d Indonesia). Skripsi S1 FEB Universitas Diponegoro. 
Suhardjanto, D. dan Lesmana, S. I. (2010) Pengaruh Karakterstik Pemerintah Daerah terhadap Tingkat Pengungkapan Wajib di Indonesia. Prestasi 3(2): 25-40

Suhardjanto, D. dan Yulianingtyas, R. R. (2011) "Pengaruh Karakteristik Pemerintah Daerah terhadap Kepatuhan Pengungkapan Wajib dalam Laporan Keuangan Pemerintah Daerah (Studi Empiris pada Kabupaten/Kota di Indonesia)”. Jurnal Akuntansi dan Auditing Volume 8(1): 30-42.

Sumardjo, H. (2010) Pengaruh Karakteristik Pemerintah Daerah terhadap Kinerja Keuangan Pemerintah Daerah (Studi Empiris pada Pemerintah Daerah Kabupaten/Kota di Indonesia. Skripsi. FEB Universitas Sebelas Maret Surakarta.

Susbiyani, A., B. Subroto, Sutrisno, dan B. Purnomosidhi. (2014) "The compliance with Mandatory Disclousure of Financial Statement: A Study from Local Government in Indonesia”. Research Journal of Finance and Accounting 5(10): 124-130

Sutaryo. (2010) Karakteristik Eksekutif dan Kinerja Keuangan Pemerintah Daerah (Sebuah Telaah Teoritis dan Empiris). Artikel dipublikasikan diakses 5 Mei 2015 dari http.www.sutaryo.staff.uns.ac.id

Undang-Undang Republik Indonesia Nomor 15 Tahun 2004 tentang Pemeriksaan Pengelolaan dan Tanggungjawab Keuangan Negara.

Undang-Undang Republik Indonesia Nomor 17 Tahun 2003 tentang Keuangan Negara Undang-Undang Republik Indonesia Nomor 22 Tahun 1999 tentang Pemerintah Daerah Zimmerman. 1977. The Munipicial Accounting Maze: An Analysis Political Incentives. Economic Efficiency of Nonprofit Institutions. Journal of Accounting Research 15:107-144. 